\title{
Green Synthesis of Silver Nanoparticles Using Hypericum perforatum L. Extract and Evaluation of Their Antibacterial Activity
}

\author{
DANIELA GITEA, ANDREI TEODORESCU, CARMEN PANTIS, DELIA MIRELA TIT, \\ ALEXA FLORINA BUNGAU, MIHAELA BOGDAN, ILONA KATALIN FODOR*, CRISTIANA BUSTEA \\ University of Oradea, Faculty of Medicine and Pharmacy, 29 Nicolae Jiga Str., 410028, Oradea, Romania
}

\begin{abstract}
Silver nanoparticles (AgNPs) ranging in size from 1-100 nm show good application potential in many medical fields (therapies, medical devices, molecular diagnostics) due to their antimicrobial properties. The purpose of this study is to characterize from physicochemical perspective the colloidal dispersion obtained through phytosynthesis. The existence of colloidal silver particles was visually highlighted through Thyndall effect. The bioreduction of silver ions was analyzed through modern techniques, UV-VIS spectrophotometry and Hyperspectral Microscopy. After getting the colloidal dispersion, its antibacterial activity was proved by sowing on different plates the following types of pathogenic agents: Staphylococcus aureus, Escherichia coli, Pseudomonas aeruginosa. The UV-VIS spectrum for the methanolic extract with $10 \% \mathrm{H}$. perforatum $\mathrm{L}$. and for the silver colloidal dispersions was achieved, observing a max at $455 \mathrm{~nm}$. The hyperspectral images were achieved observing the shape, conformation, and the size of the obtained particles. During the antibacterial efficacy testing on those three strains of pathological agents, in all situations, the colloidal dispersion had a promising antimicrobial effect.
\end{abstract}

Keywords: green synthesis, silver nanoparticles, $H$. perforatum L., antibacterial activity

The term nanotechnology was used for the first time by Norio Taniguchi in 1974, and represents the set of technologies and researches, physical, chemical and biological at the scale of particles with size smaller than $100 \mathrm{~nm}$ [13]. Recently, the nanoparticles from noble metals have been the target of many researches concerning their unique electronic, optical, mechanical, magnetic and chemical properties. Their specific properties are different due to their dimension and the size of their specific surface [4-6]. They have applications in different fields: catalysing some reactions, in the electronic field, in photonics, in photography, in textile industry [7,8], in cosmetics industry [9], in dye industry, technical-medical products [10,11], in the diagnosis field [12], in the treatment of different acute and chronical severe diseases like malaria, hepatitis, cancer [13-16] and AIDS, and as vectors for some medicines [17,18].

The antibacterial effect of silver ions has been known for a long time: in concentrations of 1:20.000.000 affect the thiol groups, precipitating the proteins and interfering the vital enzymatic processes of bacterial cells. But the use of AgNPs as antibacterial agent is relatively new. In comparison with the silver ions, the antimicrobial activity of the colloidal silver particles is influenced by the size of the particles, their size being inversely proportional with the antimicrobial effect, due to their increased reactivity determined by the big ratio surface to volume [19].

A few preparation methods for the metallic nanoparticles were reported: reduction of some salts, radiolysis, electrochemical synthesis, laser ablation and thermal ablation. In order to get the AgNPs, the simplest method is the reduction of some silver salts - they produced nanoparticles with different morphologies and dimensions through the reduction method. A multitude of reductive agents were used for the synthesis of the stable AgNPs in aqueous environment; among these agents are: ascorbic acid [20], hydrazine [21], ammonium formiate [22], dimethylformamide [23] and sodium borohydride [24].

It was possible to phyto-synthesize metallic nanoparticles of silver, gold, platinum, palladium, copper, zinc and iron with the help of algae, actinomycetes, bacteria, fungi and plants [25]. In the case of the synthesis based on plant use, a range of different vegetal products (root, stem, bark, fruits, seeds, latex, gums) from a variable number of plant species were proven to be able to generate nanoparticles [26]. These phyto-syntheses are considered green syntheses [1].

*email: katifodor@yahoo.com 
The biological preparation methods are less expensive than the physical or chemical ones, needing even less subsequent processing stages, the synthesis occurring at physiological pressure, temperature and $\mathrm{pH}$. It is a relatively faster synthesis method, and the size of the obtained particles is controllable [27,28]. The inorganic nanoparticles phytosynthesized are more biocompatible and less damaging for the environment [29]. It is an eco-friendly method, with limited toxicity.

The silver and gold nanoparticles synthesis with Mentha piperita extract was proven possible. The menthol particles from leaves extract acted as bio-reducer and made the synthesis of silver and gold nanoparticles possible. The nanoparticles were active against a few Staphylococcus aureus and Escherichia coli strains isolated from human biological fluids [1,30,31]. Metallic nanoparticles can be purified through centrifugation, ultracentrifugation, high performance liquid chromatography (HPLC) or ionic exchange. They can be characterized UV-VIS spectrometry, infrared spectrometry with transformation Fourier (FT-IR) or Raman, or with the help of a scanning electronic microscope (SEM) $[1,32]$.

Hyperici herba is the blooming end part of the plant Hypericum perforatum L. from the Hypericaceae family, also known as St. John's worth, dried after harvest [33]. The main active substance is hypericin, of red-violet color, which, unlike the majority of active anthraquinone principles from other plants, does not have laxative-purgative activity. From a chemical point of view, hypericin is a biantrone, an anthraquinone derivative, red. In the vegetal product are also present its oxidized derivative, pseudo hypericin, and isomers of these two compounds, proto hypericin and proto pseudo hypericin [34]. Clearly, as for any plant, the concentration of active compounds in the different parts of the plant varies depending on the soil's characteristics [35,36] and climatic conditions [37].

The flavonoid derivatives from the composition include the hyperoside, izoquercitrin, rutoside, luteolin, kaempferol and biflavonoids: amentoflavone and biapigenin. It contains hyperforin, which has a particular structure: it belongs to the phloroglucinol class and it was one of the first compounds identified from this group [38]. Studies were carried out regarding its antibacterial activity against Staphylococcus aureus MRSA strains, with MIC values of 0.1-1 mg/L [39]. It contains 13-17\% tannin. The plant also contains caffeic acid, chlorogenic acid and a range of xantones.

\section{Experimental part}

\section{Plant material}

The analyzed vegetal material consists of the aerial parts of the plant $H$. perforatum $\mathrm{L}$. which vegetates in the area of Bihor County. The vegetal product used, was harvested in June 2017 from the area of Bors, Bihor County, Romania. The identification of the species was made considering the basic morphological characteristics of the aerial parts (stem, leaves, flowers), identified at the place of harvest, or using the plans made by pressing the vegetal material. The herbal plans with pressed plants are stored in the Herbarium of the Faculty of Medicine and Farmacy Oradea.

\section{Extracts preparation}

The extraction method chosen was Soxhlet extraction, using an installation with the same name. Through several extraction cycles, the yield of the process can be controlled making the extraction as complex as possible. To get the methanolic extract, $10 \mathrm{~g}$ vegetal product and $90 \mathrm{~mL}$ pure methanol were used. The temperature of the water bath was $60^{\circ} \mathrm{C}$. The extraction was done in a Soxhlet installation, through 5 cycles of circulation of the solvent through installation, for 9 hours.

\section{Synthesis and characterization of AgNPs}

To obtain the AgNPs a fast synthesis method was used, with reduced toxicity, an eco-friendly method, bottom-up approach. The reduction of silver ions was performed successfully with the help of Hyperici herba extract. The AgNPs was obtained adding $1 \mathrm{~mL}$ methanolic extract over $9 \mathrm{~mL}$ silver nitrate $1 \mathrm{mM}$. The reduction of $\mathrm{Ag}^{+}$ions to $\mathrm{Ag}^{0}$ was evident from the slow color change and the reaction was completed with a stable light yellowish brown colour of the solution, which indicated the formation of colloid. The characterization of the colloidal dispersion was made through UVVIS spectrophotometry (Spectrophotometer T70+) and through hyperspectral microscopy in dark field, patent CytoViva, from Vasile Goldis Western University of Arad. The powder of nanoparticles was investigated using FTIR (Fourier Transform Infrared Spectroscopy), in the range of $400-4000 \mathrm{~cm}^{-1}$; the apparatus was a Spectrum BXII spectrophotometer (PerkinElmer), equipped with MIRacle ATR accessory (ZnSecrystal). The nanoparticles were freeze-dried (using Martin Christ Alpha 1-2 LD equipment) for ATR-FTIR. 
The antibacterial efficacy test for this dispersion, in comparison with control samples and samples with antibiotics, was performed in the Microbiology Laboratory from the Clinical Hospital of Pneumophtisiology, Oradea, the Bacteriology Laboratory compartment, through standardized diffusion method (Kirby-Bauer). This method does not provide information about the minimal inhibitory concentration but shows the sensitivity of a species to the antibiotics used.

The inoculum is a microbial suspension obtained from a culture developed in 16-18 $\mathrm{h}$ on solid culture medium and adjusted according to the nephelometric standard McFarland $0.5\left(10^{8} \mathrm{CFU} / \mathrm{mL}\right)$. It was sown in canvas on each plate with agar Mueller-Hinton. The preparation of the calibrated suspension and the sowing on culture medium had to be performed in maximum 20 minutes. The bacterial strains used were Escherichia coli ATCC 25922, Staphylococcus aureus ATCC 25923 and Pseudomonas aeruginosa ATCC 27853. The plates with Mueller-Hinton culture medium were sowed at 15 minutes after calibration, using new, sterile tampons, and after inoculation were left to dry for 3-4 minutes before the application of the discs with antibiotics. The plate was sowed with the tampon, turning it $60^{\circ}$ for 3 times. The tampon was not reused during inoculation.

\section{Results and discussions}

\section{Characterization of AgNPs}

The Tyndall Effect

The Tyndall effect is an optical property of colloidal dispersions, being the most convenient method of differentiating a colloidal dispersion of a solution. To prove that the silver particles formed are within the limits of colloidal size, the dispersion to a light beam was examined. The formation of the light cone (due to the silver particles of colloidal size) was observed (Figure 1).

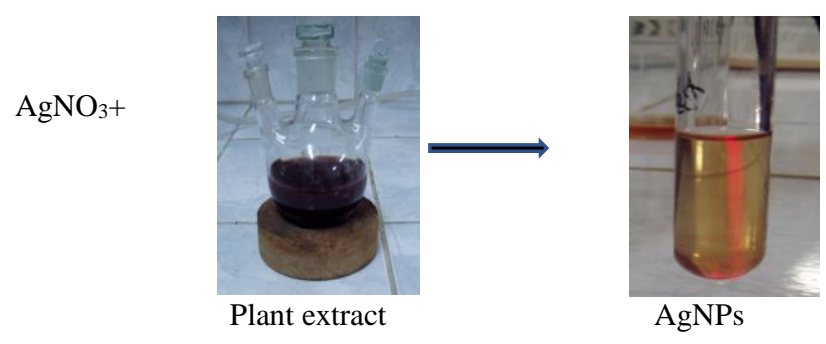

Fig. 1. Preparation of silver nanoparticles and Tyndall effect

\section{UV-VIS spectral studies}

The UV-VIS spectrum was determined for colloidal dispersion obtained from the methanolic extract and the silver nitrate solution. The interval of the wavelengths used was between 400 and $700 \mathrm{~nm}$. Hyperici herba has as main component hypericin, a red-colored naphthodianthrone, with a specific peak at $590 \mathrm{~nm}$ [40]. For the colloidal silver dispersion, the evolution of the UV-VIS spectrum during a period of 3 days from the date of preparation was studied. Figure 2 presents the evolution of the colloidal silver dispersion UV-VIS spectrum.
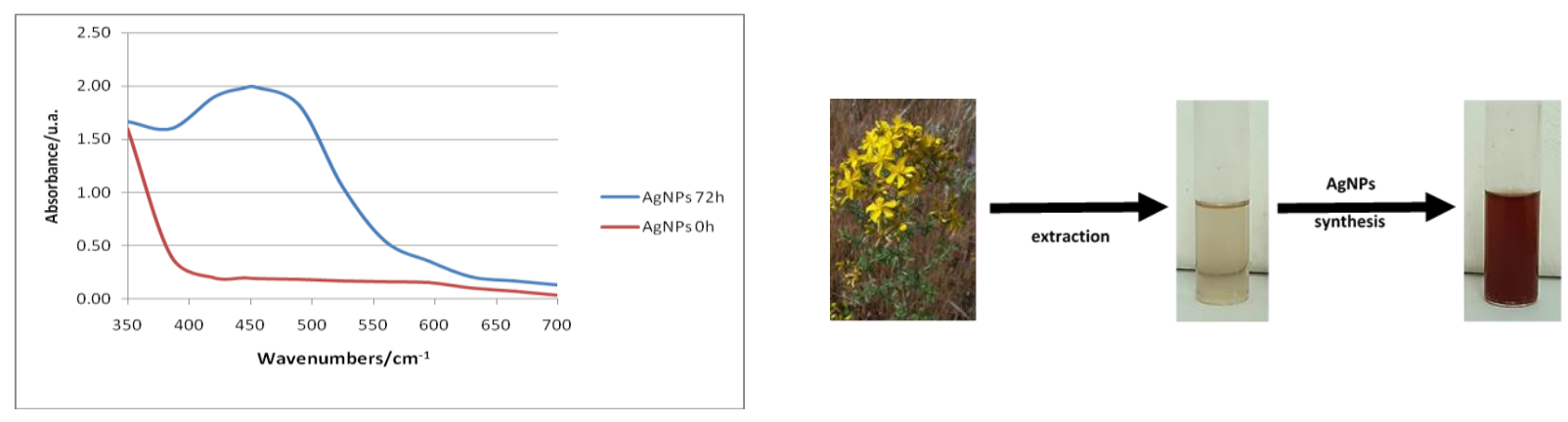

Fig. 2. The evolution of the colloidal silver dispersion UV-VIS spectrum 
Analyzing the spectrum of the silver colloidal dispersion, a maximum was observed at $455 \mathrm{~nm}$. Considering the bibliographic data in this field, the silver colloidal particles with size of $100 \mathrm{~nm}$ absorb the light [30,31].

\section{ATR FTIR spectroscopy}

A comparison of ATR FTIR spectra is presented in figure 3.

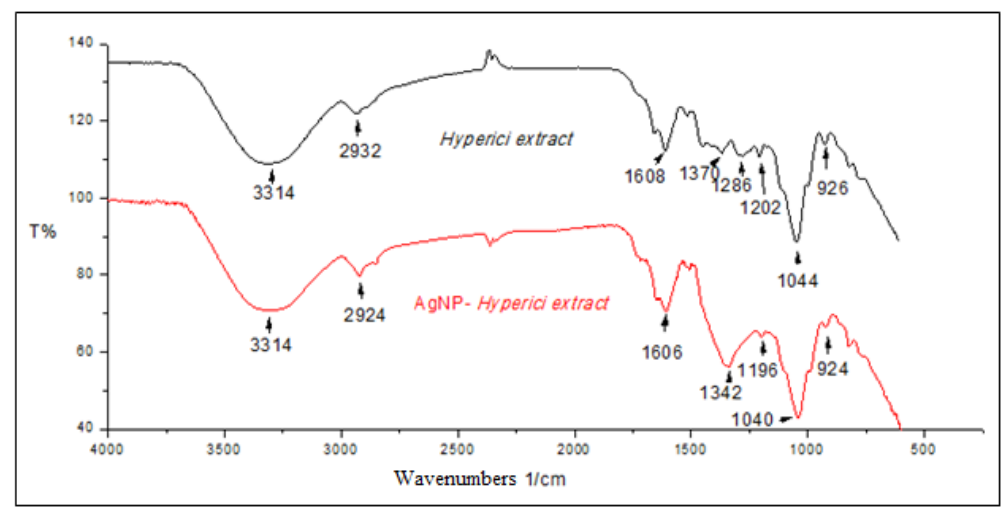

Fig. 3. ATR FTIR spectra and AgNPs Hyperici extract

When interpreting the FTIR spectrum of Hyperici extract, vibrations are attributed considering those characteristics of hypericin, the main component in the extract. Hypericin being a bianthrone (an anthraquinone derivative), therefore, for the interpretation of the FTIR spectrum, the vibrations that appear in the FTIR spectra of anthraquinone are also considered [41-44].

The FTIR spectrum of the Hyperici extract has bands between $700-1050 \mathrm{~cm}^{-1}$ attributed to deformation vibrations in the plane and out of the plane, as well as to the stretching vibration of the benzene rings. In addition, the stretching vibration of the carbonyl group is present at $1608 \mathrm{~cm}^{-1}$ as a mark of the hypericin from the Hyperici extract. The vibration at $926 \mathrm{~cm}^{-1}$ corresponds to the plane deformation of the C-C-C and C-C-H bonds. The strong vibration at $1044 \mathrm{~cm}^{-1}$ corresponds to C-O stretch, C-C-C and H-O-C in plane deformation. In the FTIR spectrum appear a few peaks of average intensity, the most important being: $1202 \mathrm{~cm}^{-1}$ - the deformation vibration in plane $\mathrm{C}-\mathrm{C}-\mathrm{H} ; 1286 \mathrm{~cm}^{-1} \mathrm{C}-\mathrm{C}$ bond stretching vibration and $\mathrm{C}-\mathrm{C}-\mathrm{H}$ and $\mathrm{H}-\mathrm{O}-\mathrm{C}$ bonds in plane deformation; at $1370 \mathrm{~cm}^{-1} \mathrm{C}-\mathrm{C}$ aromatic stretching, deformation in plane of the methyl group and phenolic $\mathrm{OH}$ groups; at $1608 \mathrm{~cm}^{-1} \mathrm{C}-\mathrm{C}$ stretch and deformation of $\mathrm{H}-\mathrm{O}-\mathrm{C}$. A low intensity vibration can be observed at $2932 \mathrm{~cm}^{-1}$, representing the asymmetric stretching vibration of the metal group; at $3314 \mathrm{~cm}^{-1}$ there is an intense, wide vibration that corresponds to the stretching of the associated $\mathrm{OH}$ group.

After the colloid formation, some of the vibrations change slightly their wavelength and some disappear (the most important being at $1286 \mathrm{~cm}^{-1}$ that no longer appears, probably due to the formation of colloid). The stretching vibration intensity $v$ (ring) at $1017 \mathrm{~cm}^{-1}$ is strongly strengthened and slightly displaced in the colloid spectrum.

The characteristic deformation band outside the plane $\gamma(\mathrm{CH})$ from the ring, which appears at $811 \mathrm{~cm}^{-1}$ as a narrow band of medium intensity, changes its intensity in the colloid spectrum. It is noted that in the colloid spectrum the wide and intense band is maintained at a lower frequency at $3400-3200 \mathrm{~cm}^{-1}$, characteristic to the $-\mathrm{O}-\mathrm{H}-\ldots \mathrm{O}$ bond of the associated phenolic hydroxyl groups.

\section{Hyperspectral Microscopy}

In figure 4 are displayed the images from the hyperspectral microscope, of silver particles obtained through phytosynthesis. The particles have a rounded shape, the size over $100 \mathrm{~nm}$, red color inside and silver color in the outside. Due to this fact it was concluded that the particle was formed by embedding the lipophile hypericin, the active principle of red color from Hyperici herba, by the silver ions.

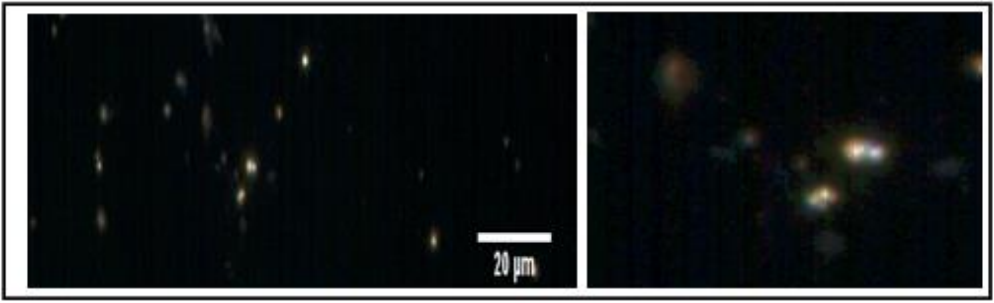

Fig. 4. Images of silver colloidal particles $60 \mathrm{x}$ 


\section{The antibacterial activity}

The disks imbued with the solutions to be analyzed were placed at equal distances. The plates were incubated for $16 \mathrm{~h}$ at $35^{\circ} \mathrm{C}$ in wet atmosphere with $5 \% \mathrm{CO}_{2}$, with the lid downwards (Figure 5). The results were read measuring the diameters of the inhibition areas using the graduated ruler, in millimeters (Table 1).

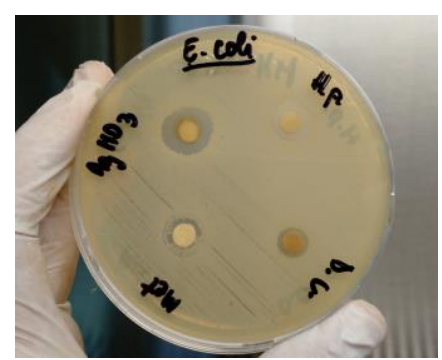

a

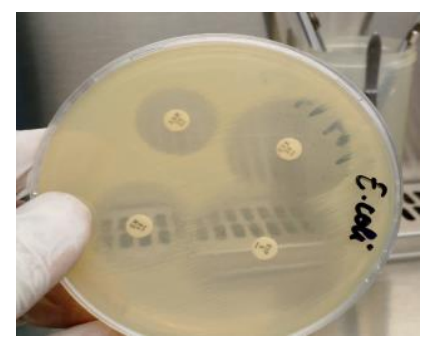

$\mathrm{a}_{1}$

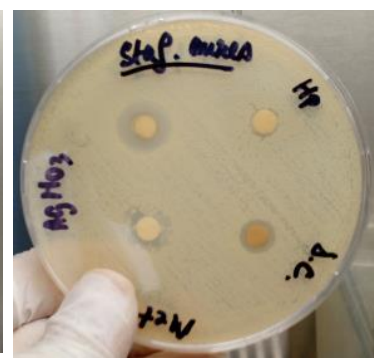

b

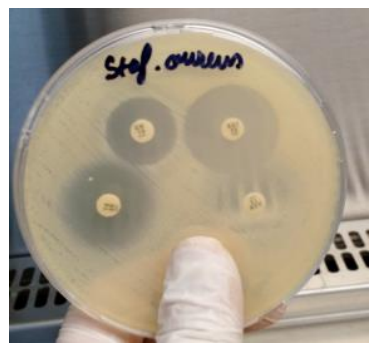

$b_{1}$

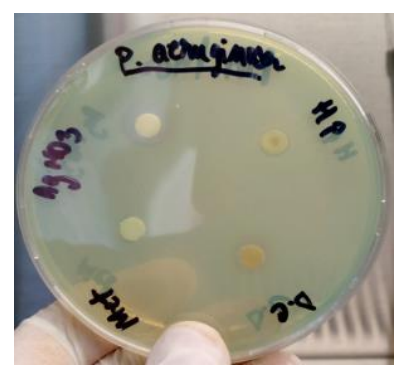

c

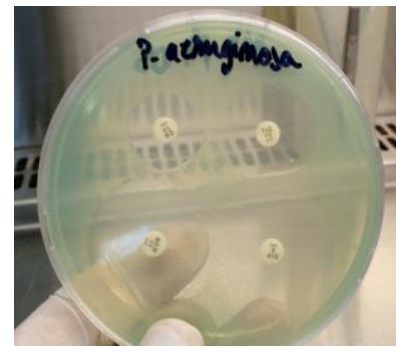

$\mathrm{C}_{1}$

Fig. 5. Inhibition zones for colloidal dispersion and control samples for E. coli (a), S. aureus (b), $P$. aeruginosa (c); Inhibition zones for: ampicillin + sulbactam, cefotaxime ciprofloxacin and gentamicin for E. coli (al); gentamicin, ciprofloxacin, trimethoprim + sulfamethoxazole and tetracycline for $S$. aureus $\left(\mathrm{b}_{1}\right)$ and gentamicin, azithromycin, meropenem and ticarcillin for $P$. aeruginosa $\left(\mathrm{c}_{1}\right)$

Table 1

THE MEAN INHIBITION RANGE OF AgNPs

\begin{tabular}{|c|c|c|c|}
\hline \multirow{2}{*}{ Samples } & E. coli & S. aureus & P. aeruginosa \\
\cline { 2 - 4 } & \multicolumn{3}{|c|}{$(\mathrm{mm})$} \\
\hline Colloidal dispersion & 8 & 9 & 9 \\
\hline Hyperici herba extract & 11 & 8 & 8 \\
\hline AgNO3 & 15 & 13 & 14 \\
\hline Methanol & 10 & 0 & 11 \\
\hline Ampicillin + Sulbactam & 20 & - & - \\
\hline Cefotaxime & 30 & - & 20 \\
\hline Gentamicin & 17 & 18 & - \\
\hline Ciprofloxacin & 30 & 31 & - \\
\hline Tetracycline & - & 26 & - \\
\hline Azithromycin & - & 20 & 17 \\
\hline Meropenem & - & - & 25 \\
\hline Ticarcillin & - & - & - \\
\hline
\end{tabular}

The most powerful antibacterial effect was observed with cefotaxim and ciprofloxacin on the E. coli strain, trimethoprim+sulfamethoxazole on the $S$. aureus strain, and meropenem on the $P$. aeruginosa strain. Colloidal dispersion had a lesser antibacterial effect than the $H$. perforatum L. methanolic extract on $E$. coli strains, but on $S$. aureus and $P$. aeruginosa strains the colloidal dispersion had a more potent antibacterial effect than the extract. In all cases, the colloidal dispersion had a much weaker effect than the silver nitrate solution, in a case even a lower effect than the methanolic extract of $H$. perforatum, and in two cases a lesser effect than the pure methanol. In all cases, colloidal dispersion had a much weaker effect than all antibiotics to which the species of the micro-organism was sensitive. It is possible to produce a reciprocal decrease in the antibacterial effect of silver and hyperforin [45,46]. 
Manoj L. and collaborators obtained AgNPs with antibacterial activity using Hypericum hookerianum extract. They have demonstrated a strong antibacterial action on the species of B. subtillis (Gram + ) and P. aeruginosa (Gram -) [31]. Nazari Z. et al demonstrated the antibacterial action of AgNPs obtained by using as a reducing agent Hypericum scabrum seed extract on Gram + bacteria (Staphylococcus aureus and Streptococcus mutans) in particular, compared to Gram (Salmonella typhi, Escherichia coli) [47].

Ozgen A. et al, in 2019, demonstrated the antibacterial action of colloidal Ag particles obtained with an aqueous extract of $H$. perfortum leaves. They had an antibacterial action on Gram + and - bacteria, varying according to the volume of solution added to the impregnation discs. The inhibition diameter ranges from $8 \mathrm{~mm}$ (for a volume of $2 \mu \mathrm{g} /$ disc, on E. coli strains) to $35 \mathrm{~mm}$ (for a volume of $15 \mu \mathrm{g} /$ disc). As the volume increases, the inhibition area increases proportionally [48].

As the mechanism of action of colloidal Ag particles, it is known that they interact with the bacterial cell, reaching Gram negative bacteria to accumulate at the surface of the cell and to produce structural changes of the bacterial wall, thus increasing its permeability. The size of AgNPs, their shape and concentration influence the adhesion to the bacterial wall $[49,50]$.

\section{Conclusions}

The obtaining of the colloidal dispersion was proved through the forming of the light cone specific to the Tyndall effect. The UV-VIS spectrum for the methanolic extract with $10 \% H$. perforatum L. and for the silver colloidal dispersions was achieved, observing a maximum at $455 \mathrm{~nm}$. The hyperspectral images were obtained, observing the shape, conformation, and the size of the resulted particles. During the antibacterial efficacy testing on those three strains of pathological agents, in all situations, the colloidal dispersion shown a promising antimicrobial effect.

\section{References}

1.HALEEMKHAN, A.A., NASEEM, B., VARDHINI, V., , Int. J. Mod. Chem. Appl. Sci., 2, nr. 3, 2015, p. 195.

2.OTRISAL, P., OBSEL, V., BUK, J., SVORC, L., Nanomaterials, 8, nr. 8. 2018, p. 564. https://doi.org/10.3390/nano8080564.

3.PRIKRYL, R., OTRISAL, P., OBSEL, V., SVORC, L., KARKALIC, R., BUK, J., Nanomaterials, 8, nr. 9, 2018 , p 679. https://doi.org/10.3390/nano8090679.

4.MARIES, G.R.E., CHIRA, D., BUNGAU, C., COSTEA, T., MOLDOVAN, L. Mater. Plast., 54, nr. 2, 2017 , p. 214.

5.GUZMAN, M.G., DILLE, J., GODET, S., Int. J. Chem. Biomol. Eng., 2, nr. 7, 2008, p. 91.

6.MAZUR, M., Electrochem. Commun., 6, 2004, p. 400.

7.OTRISAL, P., MELICHARIK, Z., SVORC, L., BUNGAU, S., VIRCA, I., BARSAN, G., MOSTEANU, D., Mat. Plast., 55, no. 4, 2018 , p. 545. 8.CUC, S., TRIPA, S., BUNGAU, C., 5th Review of Management and Economic Engineering International Management Conference, Cluj Napoca, Romania, 2016, p. 100-+.

9.BOGDAN, M., ENDRES, L., PASCA, B., TIT, D.M., UIVAROSAN, D., COPOLOVICI D.M., ALEYA, L., BUNGAU, S., Mat. Plast., 56, nr. 1, 2019, p. 133.

10.BARTOS, D., DIACONU, C., BADILA, E., DARABAN, A.M. Farmacia, 62, no. 5, 2014, p. 811-823.

11.TICA, O.A., TICA, O., ANTAL, L., HATOS, A., POPESCU, M.I., PANTEA STOIAN, A., BRATU, O.G., GAMAN, M.A., PITURU, S.M., DIACONU, C.C. Farmacia, 66, no. 6, 2018, p. 972-976.

12.DIACONU, C.C., DUMITRU, N., FRUNTELATA, A., LACAU, S. BARTOS, D. Acta Cardiologica Sinica, 31, no. 1, 2015 , p. 83-86.

13.DIACONU, C.C., ARSENE, D., BALACEANU, A., BARTOS, D. Romanian Journal of Morphology and Embryology, 55, no. 3, 2014, p. 973976.

14.PARASCHIV, B., TOMA, C.L., DIACONU, C.C. Archivos de Bronconeumología, 49, no. 7, 2013, p. 315-316.

15.SOCEA, L.I., VISAN, D.C., BARBUCEANU, S.F., APOSTOL, T.V., BRATU, O.G., SOCEA, B. Rev. Chim., 69, no. 4, 2018 , p. $795-797$.

16.PAHONTU, E., SOCEA, L.I., BARBUCEANU, S.F., ILIES, D.C., BADEA, M., OLARU, O.T., GULEA, A., SOCEA, B., BRATU, O. Rev Chim (Bucharest), 69, nr. 11, 2018, p. 2959-2963.

17.ALBRECHT, M.A., EVANS, C.W., RASTON, C. L., Green Chem., 8, no. 5, 2006, p. 417.

18.GINGHINA, O., BURCEA-DRAGOMIROIU, G.T.A., GALATEANU, B., et al. Farmacia, 67, nr.1, 2019, p.18-26.

19.SHAHVERDI, A.R., FAKHIMI, A., SHAHVERDI, H.R., MINAIAN, M.S., Nanomed., 3, 2007, p. 168.

20.AL-THABAITI, S.A., AL-NAWAISER, F.M., OBAID, A.Y., AL-YOUBI A.O., KHAN, Z., Colloid Surface B, 67, 2008 , p. 230.

21.KHAN, Z., AL-THABAITI, S.A., EL-MOSSALAMY, E.H., OBAID, A.Y., Colloid Surface B, 73, 2009 , p. 284.

22.WON, H.II., NERSISYAN, H., WON, C.W., LEE, J.-M., HWANG, J.S., Chem. Eng. J., 156, 2010, p. 459.

23.PASTORIZA, I., LIZ-MARZAN, L. M., Pure Appl. Chem., 72, 2000, p. 83.

24.SOLOMON, S.D., BAHADORY, M., JEYARAJASINGAM, A.V., RUTKOWSKY, S.A., BORITZ, C.J., J. Chem. Edu., 84, 2007, p. 322.

25.HUSSAIN, J.I., KUMAR, S., HASHMI, A.A., KHAN, Z., Adv. Mat. Lett., 2, nr. 3, 2011, p. 188.

26.FIERASCU, I., BUNGHEZ, I.R., FIERASCU, R.C., ION R.M., DINU-PIRVU, C.E., NUTA, D., Farmacia, 62, nr. 1, 2014 , p. 129.

27.ROY, N., BARIK, A., Int. J. Nanotechnol., 4, 2010, p. 95.

28.INGALE, A.G., CHAUDHARI, A.N., J. Nanomed. Nanotechol., 4, 2013, p. 1.

29.RAMTEKE, C., CHAKRABARTI, T., SARANGI, B. K., PANDEY, R.A., J. Chem., 2013, p.1.

30.ALI, D.M., THAJUDDIN. N., JEGANATHAN, K., GUNASEKARAN, M., Colloid Surface B, 85, nr. 2, 2011 , p. 360. 
31.MANOJ, L., VISHWAKARMA, V., SAMAL, S.S., SEENI, S., J. Exp. Nanosci., 10, nr. 3, 2015, p. 181.

32.OLTEANU, R. L., NICOLESCU, C. M., BUMBAC, M., Analyt. Lett., 50, nr. 17, 2017, p. 2786.

33.SARBU, I., STEFAN, N., OPREA A., Vascular Plants of Romania, illustrated land determinator (in Romanian: Plante vasculare din Romania, determinator ilustrat de teren), Victor B. Victor Ed., Bucharest, 2013, pp. 448-452.

34.GITEA, D., Species of Hypericum in Phytotherapy (in Romanian: Specii de Hypericum in fitoterapie), University of Oradea Ed., Oradea, 2015, pp. 98-105.

35.SAMUEL, A.D., BREJEA, R., DOMUTA, C., BUNGAU, S., CENUSA, N., TIT, D.M., J. Environ. Prot. Ecol, 18, nr. 3, 2017 , p. 871.

36.SAMUEL, A.D., TIT, D.M., MELINTE (FRUNZULICA), C.E., IOVAN, C., PURZA, L., GITEA, M., BUNGAU, S., Rev. Chim., 68, no. 10, 2017, p. 2243.

37.GITEA, M.A., GITEA, D., TIT, D.M., PURZA, L., SAMUEL, A.D., BUNGAU, S., BADEA, G.E., ALEYA, L. Environ. Sci. Pollut. Res. Int., 26, nr. 10, 2019, p. 9908. https://doi.org/10.1007/s11356-019-04214-1

38.GITEA, D., VICAS, S., GITEA, M.A., NEMETH, S., TIT D.M., PASCA B., PURZA L., IOVAN, C., Rev. Chim., 69 , no. 2 , p. 305.

39. HEINRICH, M., BARNES, J., GIBBON, S., Fundamentals of Pharmacognosy and Phytotherapy, Elsevier Science Ed., Churchill Livingstone, 2004 , p. 258.

40.HEAD, C. S., LUU, Q., SERCARZ, J., SAXTON, R., World J. Surg. Oncol., 4, nr. 87, 2006. doi 10.1186/1477-7819-4-87

41.ZAVOI, S., FETEA, F., RANGA, F., POP, R.M., BACIU, A., SOCACIU, C., Not. Bot. Horti. Agrobo., 39, nr. 2, 2011 , p. 82.

42.SVORC, L., HASSO, M., SARAKHMAN, O., KIANICKOVA, K., STANKOVIC, M.D., OTRISAL, P., Microchem. J., 142, 2018. doi 10.1016/j.microc.2018.07.007

43.CARAC, A., BOSCENCU, R., DEDIU, A.V., BUNGAU S.G., DINICA R.M., Rev. Chim., 68, no. 7, 2017 , p. 1423.

44.CARAC, A., BOSCENCU, R., CARAC, G., BUNGAU S.G., Rev. Chim., 68, no. 10, 2017, p. 2265.

45.RADULESCU, A., MADAN, V., AUNGURENCI, A., BRATU, O., FARCAS, C., DINU, M., MISCHIANU, D. Romanian Journal of Military Medicine, 118, nr. 3, 2015, p. 20-22.

46.SPINU, D., BRATU, O., POPESCU, R., MARCU, D., RADULESCU, A., MISCHIANU, D. Romanian Journal of Military Medicine, 118, nr. 3, 2015, p. 12-15.

47.NAZARI, Z., SHAFAGHAT, A., Inorg. Nano-Met. Chem., 47, nr. 6, 2017, p. 870.

48.OZGEN, A., BILGIC, E., AYDIN, S. G., NIZAMLIOGLU M., Med. Sci. Monit., 2019. doi: 10.5455/medscience.2018.07.8985

49.FRANCI, G., FALANGA, A., GALDIERO, S., PALOMBA, L., RAI, M., MORELLI, G., GALDIERO. M., Molecules, 20, nr. 5, 2015 , p. 8856. 50.NICOLETA, P., GINGHINA, R., PRETORIAN, A., PETRE, R., BARSAN, G., OTRISAL, P., MOSTEANU, D.E., Rev. Chim., 69, no. 7, 2018, p. 1640 .

$\overline{\text { Manuscript received: 26.07.2019 }}$ 